\title{
Coastal Investigations for Sustainable Development of Fisheries Infrastructure
}

\section{A. H. R. Ratnasooriya and S. P. Samarawickrama}

\begin{abstract}
Plans have been formulated by the government to increase the fish production and the national targets indicate significant increases in marine fisheries production. The expansion of the marine fishing fleet and the development of appropriate fisheries infrastructure for the operation of such craft would play a vital role in achieving the future targets for fish production. A number of studies were thus conducted to assess the feasibility of developing sustainable fisheries infrastructure in various parts of the country. The attention in these investigations was mainly focussed on related coastal engineering aspects in order to minimise the adverse impacts on the facility as well as the neighbouring coastline to ensure the sustainability and effectiveness of any proposed development. Attempts were made to assess, qualitatively, the exposure of the sites to the nearshore wave climate and the resulting coastal processes related to sediment (sand) transport in the vicinity. The forms of coastal constructions required were identified and the severity of potential impacts due to such developments was considered to assess the suitability of the sites for potential development. The details of selected investigations conducted in eastern, northern, south-western and southern regions are presented and the recommendations are elaborated.
\end{abstract}

Keywords: Coastal, Fisheries Infrastructure, Sustainable Development.

\section{Introduction}

Fisheries activities are carried out along almost the entire coastline of Sri Lanka extending over $1,600 \mathrm{~km}$. A large coastal population is engaged in fisheries activities and, with more than 250,000 active fishermen [7], the fisheries sector forms an important part of the national economy. It accounted for $1.8 \%$ of the Gross Domestic Product of the country in 2013 [7]. Marine fishing, dominating the fisheries sector, contributes to more than $85 \%$ of total fish production [7] and is carried out by a variety of fishing crafts. These include smaller fishing crafts-Beach Seine Boats (NBSB), NonMotorized Traditional Boats (NTRB), Motorized Traditional Boats (MTRB), Outboard Motor Fibre Reinforced Plastic Boats (OFRP) and larger fishing crafts-One Day Boats with Inboard Engines (IDAY) and Multi Day Boats (IMUL)(Figure 1). The total marine fishing fleet exceeded 53,000 crafts in 2012 [7] and is based in various fishery infrastructure facilities in the form of Fishery Harbors, Anchorages and Landing Sites along the coastline of the country. Smaller fishing boats are generally concentrated at a large number of Landing Sites scattered along the coastline. The IMUL Boats and IDAY Boats are generally based at various Fishery Harbors and Anchorages. In 2012, 19 Fishery Harbors and many Anchorages were in operation [6].
Plans have been made by the Ministry of Fisheries and Aquatic Resources to increase the fish production and the national fish production targets indicate significant increases in marine fisheries production. The expansion of the marine fishing fleet and the development of appropriate fisheries infrastructure facilities for the operation of such crafts would thus play a vital role in achieving the future targets for fish production.

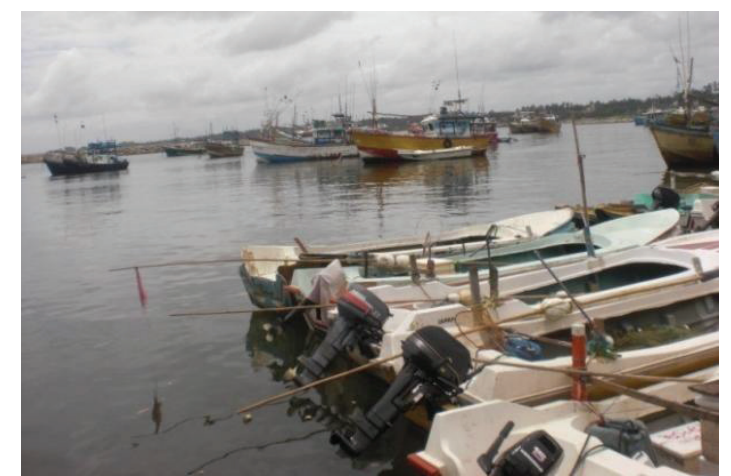

Figure 1 - Different Types of Fishing Crafts

Eng. A. H. R. Ratnasooriya, AMIE(Sri Lanka), B.Sc.Eng.(Hons) (Moratuwa), M.Phil (Moratuwa), Senior Lecturer, Department of Civil Engineering, University of Moratuwa, Sri Lanka.

Eng. (Prof.) S. P. Samarawickrama, C. Eng., MIE(Sri Lanka), B.Sc.Eng.Hons.(Moratuwa), PhD(London), DIC, Professor, Department of Civil Engineering, University of Moratuwa, Sri Lanka. 
Fisheries activities in the northern and eastern regions of the country were severely affected by the conflict that prevailed in the area for nearly three decades, but have recommenced and expanded since the end of the conflict in 2009. Many of the fisheries infrastructure facilities in these regions are in a dilapidated state and are in need of restoration and expansion. A number of studies were thus conducted recently, during the period 20092011 ,to assess the feasibility of developing sustainable fisheries infrastructure in various parts of the country.

In this paper, the methodology adopted in the investigations is presented first, which is followed by a discussion of coastal aspects associated with fishery infrastructure development. The details of coastal aspects, nearshore wave climate and coastal sand transport and shoreline behaviour, are then presented. After a discussion on shoreline response to coastal constructions in general, the details of investigations conducted at four locations in different parts of the country are presented. The recommendations made by the investigations are then summarized under concluding remarks.

\section{Method of Investigations}

The investigations were conducted at the sites for which improved facilities were requested by the local fishing communities, relevant authorities or other stakeholders. The attention in these investigations was mainly focussed on related coastal engineering aspects in order to minimise the adverse impacts on the facility as well as the neighbouring coastline to ensure the sustainability and effectiveness of any proposed development. In addition, socioeconomic aspects, space requirements for shore facilities and other aspects related to the development of fishery infrastructure facilities were also considered in these investigations.

In the absence of recorded coastal engineering information (primary data) at many of the locations considered, investigations were mainly based on field studies, analysis of available secondary information and local knowledge gathered through local community consultations. Attempts were made to assess, qualitatively, the exposure of the sites to the nearshore wave climate and the resulting coastal processes related to sediment (sand) transport in the vicinity. The forms of coastal constructions required were identified and the severity of potential impacts due to such developments was considered to assess the suitability of the sites for potential development.

\section{Fisheries Infrastructure and Coastal Aspects}

The fisheries infrastructure facilities provide essential shelter for mooring and/or beach landing and loading/unloading activities of fishing crafts and shore facilities for related support activities. Fishery Harbors mainly cater for the requirements of larger fishing crafts and such facilities usually consist of a basin area of sufficient size and depth usually protected by breakwaters, quay walls to facilitate loading/unloading operations and shore facilities for other related activities. Fishery Anchorages and Landing Sites mainly cater for the requirements of smaller fishing crafts but larger crafts could also use such facilities depending on the depths in the mooring areas. These facilities usually consist of a sheltered basin with natural or breakwater protection for safe mooring and shore facilities for other fisheries related activities.

The level of coastal infrastructure requirement to provide the necessary protection is closely related to the nearshore wave climate of the area. Depending on its severity, the requirement may vary from enhancing the natural shelter provided by features such as headlands and reefs to full breakwater protection.

The coastal areas of the country are predominantly sandy beaches and the construction of fisheries infrastructure in the form of breakwaters, jetties etc could cause alterations in sand movement patterns of the area. Such alterations could lead to adverse impacts in the form of coastal erosion and/or accretion in the area as well as siltation in the sheltered area, raising concerns related to the sustainability and the effectiveness of the development.

\section{Nearshore Wave Climate}

The wave climate in the coastal waters of Sri Lanka is characterized by two wave systems, the swell and the monsoonal waves. The resultant wave climate inclines towards the more dominant system. The swell, approaching from southerly direction 
throughout the year, is characterized by waves of relatively large periods and low amplitudes. The monsoonal waves are characterized by waves of relatively smaller periods and higher amplitudes. Two monsoonal periods are dominant-the south-west monsoonal period from May to September and the north-east monsoonal period from November to March. The coastal areas extending from the western region to the south-eastern region are directly exposed to the swell as well as the more dominant south-west monsoonal waves. The rest of the coastal areas are less exposed to the swell and sheltered from the south-west monsoonal waves. The coastal areas extending from the northern region to the south-eastern region are mainly exposed to the refracted swell and relatively less severe north-east monsoonal waves. The north-western coastal region is relatively well protected from these wave systems. The presence of sand bar formations along the Adam's Bridge, shallow depths and the shelter provided by the Jaffna Peninsula and the land masses of the islands located on the western side of the peninsula have restricted the penetration of waves into the north-western coastal waters in the Palk Bay area.

\section{Coastal Sand Transport and Shoreline Behaviour}

Nearshore currents, both longshore and on/offshore, generated by the interaction of the approaching waves with the sea bed and the resulting coastal processes of refraction, breaking etc, are the main causes of sand transport in coastal areas. In Sri Lanka, studies conducted have revealed a general trend of net sand movement northwards along the southwestern and western coasts, eastwards along the southern and northwards along the southeastern and southerly parts of the eastern coastline during the south-west monsoon. During the north-east monsoon, a general trend of sand movement southwards along the eastern, south-eastern and western coastlines and westwards along the southern coastline has been revealed.

However, the longshore sand transport rates depend on a number of factors including wave characteristics (height, period, angle of approach etc), bathymetric features (influencing refraction, breaking etc) and beach characteristics (geometry, size and availability of sand etc). Significant local variations of these factors are apparent in view of the diverse features in the coastal environment of the country.

Seasonal erosion and the steepening of the beaches during the monsoonal periods is also a common characteristic in many of the beaches in the country. Offshore movement and deposition of beach sand take place during these periods mainly due to the action of monsoonal waves. Beach recovery due to onshore movement of sand under the swell is apparent during the non-monsoonal periods.

\section{Coastal Constructions and Shoreline Response}

The stability of the shoreline can be assessed in terms of the 'sand budget' of a coastal cell considered in the area of interest. Coastal erosion and accretion can be considered in terms of sand imbalance due to changes in inflow and outflow rates. Such imbalances caused by the disturbances to the longshore transport have been identified as a major cause for erosion.

Coastal constructions, in the form of groynes, jetties or breakwaters could cause disturbances of longshore sand transport. Such constructions in areas of high level transport could lead to severe impacts associated with erosion, accretion and siltation. These impacts have become apparent in recent coastal infrastructure developments of Kirinda Fishery Harbor, Oluvil Port/Fishery Harbor and the Wadduwa Loading Out Point. The mitigation of the resulting adverse impacts would usually involve the structural interventions in the form of series of groynes or offshore breakwaters or other interventions such as sand nourishment,all of which would require substantial expenditure.

It is evident from these considerations that the assessment of the level of sand transport processes in a locality would play a vital role in identifying the suitability of sites for fisheries infrastructure development with coastal constructions. The infrastructure developments at such locations would cause relatively low levels of adverse impacts leading to the long term sustainability and effectiveness of the facilities.

Mathematical modelling techniques supported by detailed records of measured coastal data can be used for a more quantitative assessment of the level of coastal and transport and 
potential impacts of coastal constructions (in spite of the limitations in simulating complex coastal phenomena associated with sediment transport). However, due to the absence of relevant primary data and other constraints, the investigations were mainly based on field studies and analysis of available information of shoreline behaviour with the deductions confirmed through local community consultations whenever possible. The details of such investigations conducted at the locations listed below and shown in Figure 2 are presented.

\section{i. Vakarai Area on the Eastern Coast \\ ii. Point Pedro Area on the Northern Coast of Jaffna Peninsula}

iii. Galbokka on the South-WesternCoast

iv. Suduwella on the Southern Coast

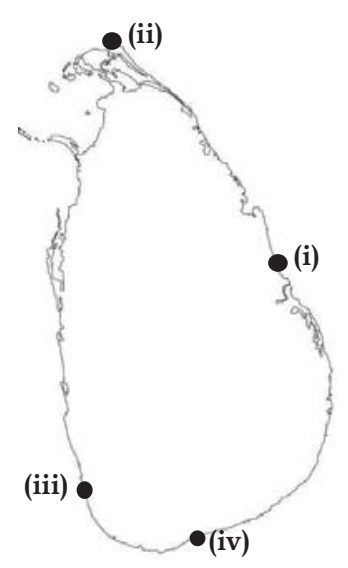

Figure 2 - Locations of Investigations

\section{Investigations in Vakarai Area on the Eastern Coast}

\subsection{Investigations in Vakarai Central}

Vakarai, with a significant fishing community, is located between Valachchenai and Trincomalee in an area where no Fishery Harbor or Anchorage facilities are located [2]. With expanding fisheries activities since 2008, a proposal has been made to develop a Fishery Harbor/Anchorage facility in the area to meet the emerging needs of fisheries sector. Vakarai Central has initially been identified for this purpose. The location of Vakarai Central is shown in Figure 3. Investigations were conducted with the objective of assessing the feasibility of developing appropriate fisheries infrastructure facilities at this location, with the attention focused on the possibility of constructing coastal structures required in the form of jetties, groynes, quay walls, breakwaters etc.

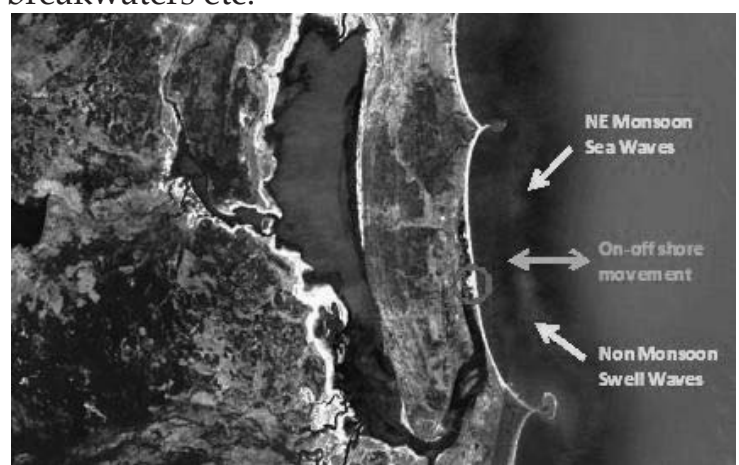

Figure 3 - Location of Vakarai Central (Source of Image: Google Earth Website)

As indicated, the site is located at the outlet of a lagoon near the centre of a coastal cell formed by two natural headlands. The coastal area is characterised by wide sandy beaches and sand deposits in shallow areas of the lagoon near the outlet and a wide sand bar across the outlet. The sand bar blocks the outflow from the lagoon but breaches during the north-east monsoon to release flood waters. Once breached, the outlet remains open for a few months. Marine fishing is carried out in the area by a large number of smaller crafts which are usually beach landed in the vicinity. Due to shallow depths in the channel through the breached sand bar, only the smaller crafts are able to access the sheltered areas in the lagoon for mooring purposes. Lagoon fishing is carried by a large number of smaller fishing crafts. Beach seine fishing is also carried out in the sandy beaches of the area.

The site is located away from the areas sheltered by the headlands and is seasonally exposed to both swell and north-east monsoonal waves as indicated in Figure 3. Significant seasonal variations of coastline positions and steepening of beaches indicate high level of longshore and on/offshore sediment transport in the vicinity. In spite of small tidal range in coastal waters of the country, a potential exists for ebb and flood tidal currents through the channel across the breached sand bar formation with accompanying sediment transport patterns. Significant variations in the form of the outlet and the lagoon sand deposits in the vicinity were also evident. The abundance of sand and the dynamic and complex nature of coastal processes and the high level of sediment 
activity in the vicinity became clearly evident by the investigations.

Coastal constructions in the form of jetties or breakwaters in such dynamic coastal environments would most likely lead to high levels of adverse impacts. These impacts in the form of severe erosion/accretion and siltation due to the disturbance caused to natural transportation processes could also affect the nearby beach seine and beach landing operations. Any structural interventions, usually in the form of groynes, to maintain an uninterrupted lagoon outlet throughout the year in order to provide mooring facilities for fishing crafts in the lagoon, are also likely to cause similar impacts leading to issues concerned with effectiveness and sustainability of the development. The changes in mixing patterns of sea water in the lagoon due to such interventions could severely affect the fishing activities and ecological aspects associated with the lagoon. In view of these considerations, the site in Vakari Central was not recommended for fishery infrastructure developments in the form of Fishery Harbors or Anchorages.

\subsection{Investigations in Alternative Sites}

In view of the complexities involved with the site identified in Vakarai Central and the need to develop Fishery Harbor/Anchorage facilities in the Vakarai area, the possibility of selecting an alternative site was also explored. Investigations were thus conducted at a number of locations in the area. These sites, functioning as landing sites with minimal facilities, had been identified by fishery sector authorities to explore the possibility of further development. The locations are listed below and shown in Figure 4.

\section{i Kathiraweli \\ ii Mahaweli River Outlets (North of \\ Kathiraweli) \\ iii Palachenai \\ iv Kandalady \\ v Vakarai \\ vi Panichankerny \\ vii Pethalai}

Investigations, similar to those conducted at Vakarai Central, were conducted for these sites as well in order to assess the potential for development of fisheries infrastructure. Based on a comparative evaluation of the level of potential for development at these locations, the site in Palachanai was identified as the most suitable site for development.

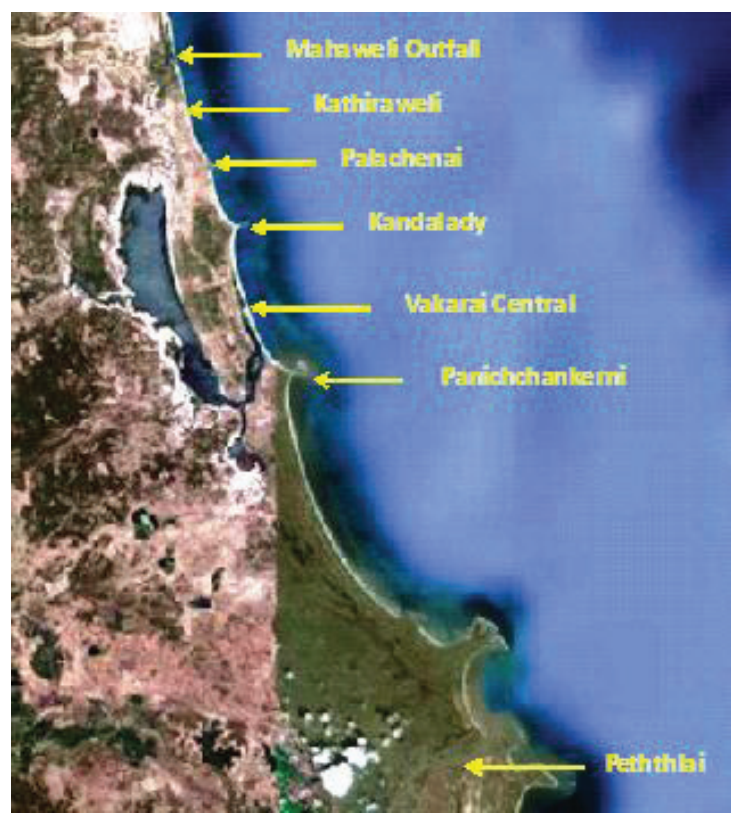

Figure 4 - Alternative Locations of Investigations

(Source of Image: Google Earth Website)

\subsection{Investigations in Palachanai}

Palachenai is located in a bay formed between two headlands, next to the northern headland formed by a rocky formation extending into the sea, as shown in Figure 5(a).

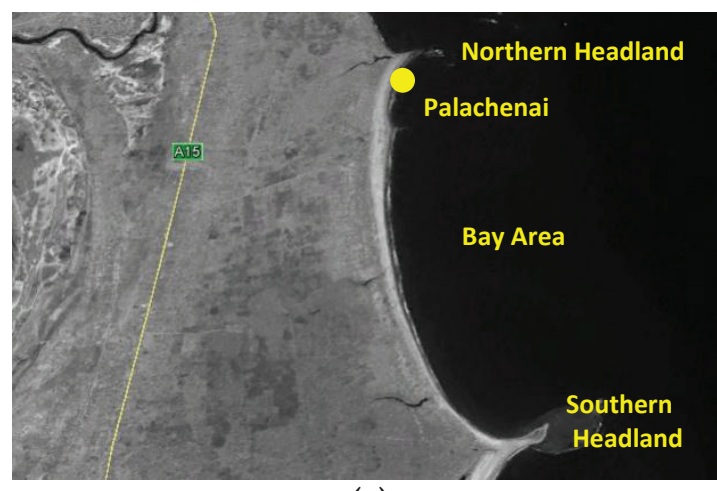

(a)

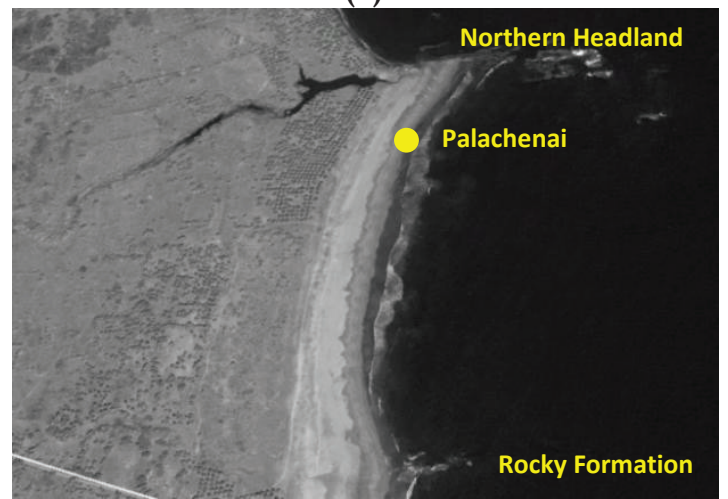

(b)

Figure 5 - Location of Palachenai (Source of Images: Google Earth Website) 
The site is partially sheltered by the rocky headland from north-east monsoonal waves. Northward sand transport is also curtailed by the headland as evident by the small scale seasonal coastal erosion on its northern side. The bay extends over a length of approximately $3.5 \mathrm{~km}$ and no large water bodies drain into the bay area. A small rocky formation, shown in Figure 5(b), exists at approximately $750 \mathrm{~m}$ from the northern headland. It restricts sediment movement and forms a smaller coastal cell in the vicinity of Palachenai. Even if a reasonable level of sediment activities is envisaged in the larger bay area, sand movement in the vicinity of Palachenai could be restricted due to the possible trapping of sediments at this rocky formation.

Based on these considerations, the site at Palachenai was identified as suitable for fishery infrastructure development. The existence of rocky outcrop providing natural protection during the north-east monsoonal period and a smaller bay area giving a relatively low level sand movement are the positive factors for such a development. The construction of a fishery infrastructure facility is unlikely to aggravate coastal erosion on the northern side of the headland. However, a small scale coast protection scheme can also be recommended together with any fishery infrastructure development. The conceptual layout of a fisheries infrastructure facility shown in Figure 6 was proposed for further investigations.

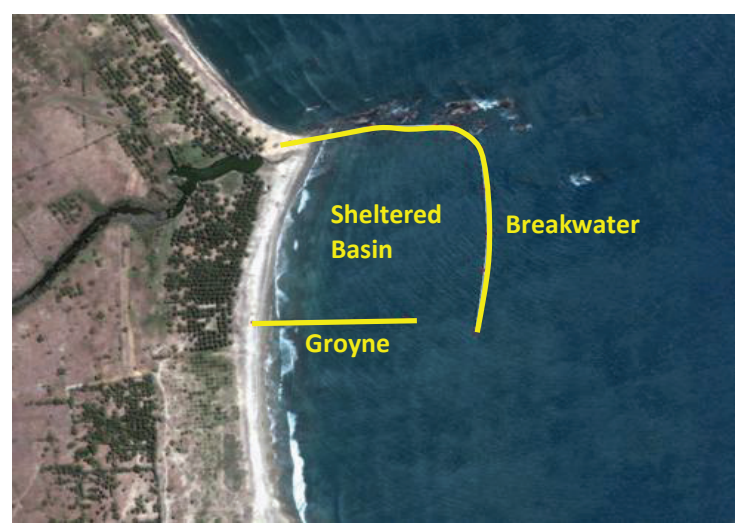

Figure 6 - Conceptual Layout of Proposed Development

(Source of Images: Google Earth Website)

\section{Investigations in Point Pedro Area on the Northern Coast of Jaffna Peninsula}

Prior to the conflict that prevailed in the region, Jaffna Peninsula had been one of the most productive fishing regions in the country. Its contribution to the national fish production had declined since mid-1980s due to the disruptions caused to the fisheries activities by the conflict[3],[4]. The fishery infrastructure facilities in the region are in a dilapidated state, due to damages caused by the conflict and years of neglect and are in need of restoration and development. Since the end of the conflict in mid-2009, the fishing sector in the northern region has shown signs of recovery with increased fish production. The fishing fleet in the area, soon after the end of the conflict, consisted of only smaller boats. In spite of the potential for offshore fishing by larger boats, such boats were not in operation due to the restrictions imposed by security conditions and the absence of adequate facilities in the region. However such boats have recently commenced operations and a need exists for the development of appropriate fisheries infrastructure facilities. Point Pedro region had been one of the most productive fishing areas in the peninsula [3],[4] and investigations were conducted to assess the potential for fishery infrastructure development in the area. The investigations were conducted in the Divisional Secretary (DS) Division of Point Pedro (Vadamarachchy North).

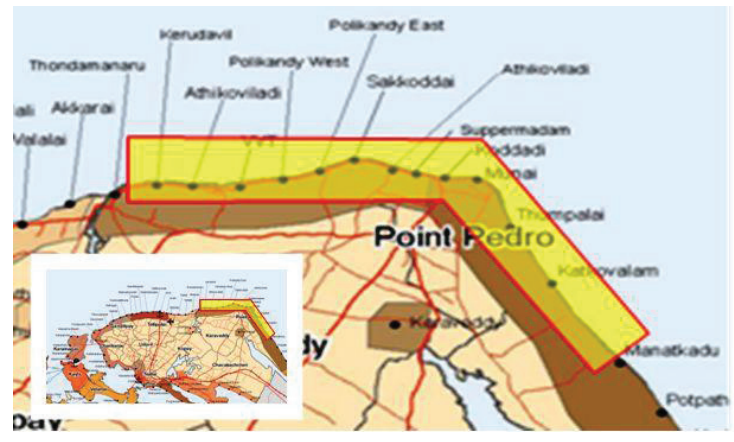

Figure 7 - Area of Investigations in Point Pedro 


\subsection{Coastal Characteristics and Fisheries Activities}

The coastline of the area of investigations extends from Thondamanaru along the northern coastline of the peninsula towards the northeastern edge of Munai and along the eastern coastline beyond Kathkovalam over a length of $20 \mathrm{~km}$ as shown in Figure 7.

The coastline on the eastern side of peninsula is directly exposed to north-east monsoonal waves and difficulties in mooring/beach landing of fishing boats are experienced by the fishing communities. As a result, relatively a lesser number of Landing Sites are located along this coastline. A wide, straight, sandy coastline exists in the area and investigations revealed significant seasonal variations of the beach profile indicating level of sediment transport. Under such dynamic conditions of the coastline, construction of coastal structures is likely to cause coastal erosion/accretion problems and such constructions without extensive investigations were not recommended.

The coastline along the northern side of peninsula in Point Pedro is characterized by rocky/sandy beaches and a reef formation located close $(<300 \mathrm{~m}$ approximately from the coastline) and parallel to the coastline as shown in Figure 8.

(a)

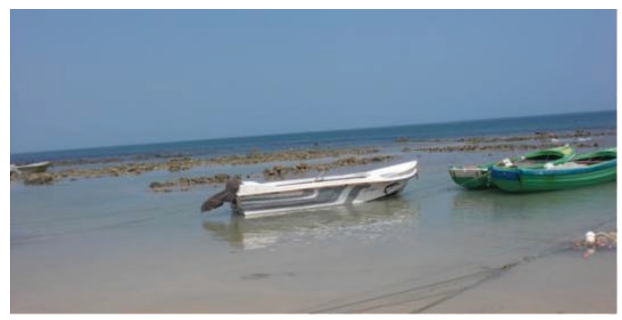

(b)

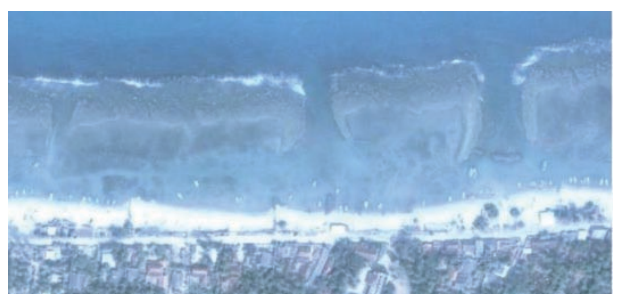

Figure 8 - Northern Coastline: Point Pedro Area

(Source of Images: Google Earth Website)

Although the coastline, by its orientation, is potentially exposed to north-east monsoonal waves, protection against coastal erosion due to wave action is provided by the reef formation along most of the coastline. The presence of reef formation has also resulted in a number of naturally sheltered basins in the area suitable for mooring of fishing craft.

Many of the Landing Sites in Point Pedro DS Division are located in such basins along this part of the coastline as indicated in Figure 9. These include the Landing Sites in Thondamanaru, Valveddithurai, Athikoviladi, Polikandy West, Polikandy East, Sakkodai, Imparsiddy, Suppermadam, Koddady and Munai. Mainly smaller fishing boats are operated from these Landing Sites. However, depending on the depths in sheltered areas behind the seaward edge of the reef formation, some of the larger boats, which have become operational recently are also based in some of the sites, in spite of the absence of proper facilities for the operation of such crafts.

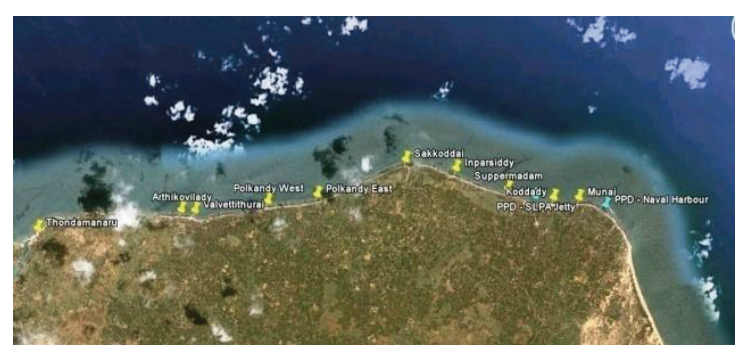

Figure 9 - Landing Sites along Northern Coastline in Point Pedro Area (Source of Image: Google Earth Website)

\subsection{Current Status of Fisheries Infrastructure and Recommendations}

The Indian Ocean Tsunami in 2004 has caused significant damages to the reef formation along the northern coast and spreading of broken rock in sheltered basins has caused difficulties in using the Landing Sites due to reduced depths and partial blockage of access channels. The cyclone in 2008 has caused further damages and significant hardships are experienced by fishing communities due to the dilapidated state of many of the facilities. Attempts have been made to rehabilitate the facilities by clearing the basin areas and access channels to facilitate navigation and mooring of boats with varying degree of success.

The improvement of fisheries infrastructure at Landing Sites, for the operation of mainly the smaller fishing crafts, in the area could generally be achieved by strengthening the natural protection provided by the reef formation. Raising the crest level of reef formation and strengthening of its seaward slope with the use of larger armour may be needed to provide effective protection. The 
clearing of scattered rocks from the access channels and sheltered basins would also be needed. Deepening of access channels and the basins may also be required at some of the sites. In such situations, due attention needs to be paid for any adverse environmental issues associated with dredging of reef formations. A possibility also exists for the use of excavated and cleared material for the use in the strengthening of protection measures.

In addition, a socio-economic need also exists for the development of appropriate infrastructure facilities, in the form of a Fishery Harbor or Anchorage, to cater for operations of larger fishing crafts. The only Fishery Harbor facility in Jaffna Peninsula is located in Myliddy on the northern coast of the peninsula to the west of Point Pedro. Fishery activities are not currently carried out at Myliddy. Even if it is operational, the potential exists for other Fishery Harbor developments in the region, mainly due to the relatively smaller size of the harbor basin in Myliddy which may not be capable of meeting the needs of the expanding fleet of larger fishing crafts in the area. In view of these considerations, recommendations were made for the development of a Fishery Harbor/Anchorage facility in Point Pedro area at an appropriate location, to be identified based on socio-economic, environmental and coastal engineering considerations. Appropriate protection measures, usually in the form of breakwaters would be required in such a development to provide a sheltered basin of adequate extent and depth against north-eastern monsoonal waves. A typical conceptual layout in the form of that shown in Figure 10 can be recommended for such a development. No severe adverse impacts associated with coastal erosion are envisaged due to such a development in view of the protection provided by the coastal reef formation in the area.

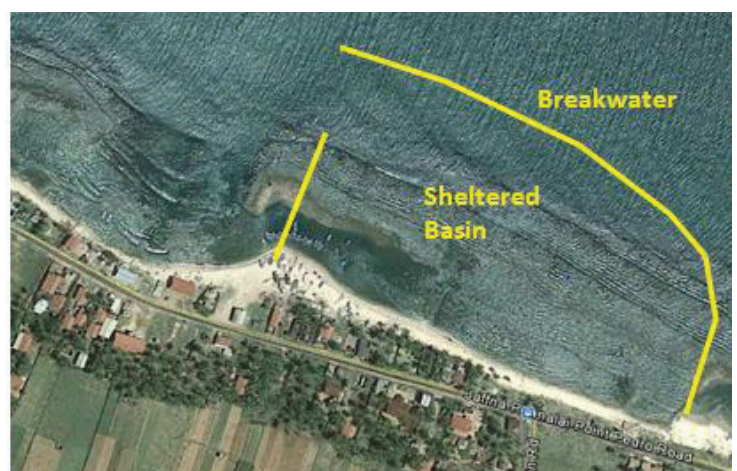

Figure 10 - Conceptual Layout of Proposed Development

(Source of Image: Google Earth Website)

\section{Investigations in Galbokka on the South-western Coast}

An investigation was conducted to assess the feasibility of developing a Fishery Landing Site in Galbokka in Rathgama in the Galle District. The site had been identified based on the availability of land to develop shore facilities due to the relocation of a school severely damaged by the Indian Ocean tsunami in 2004 [5]. The location of the site is shown in Figure 11.

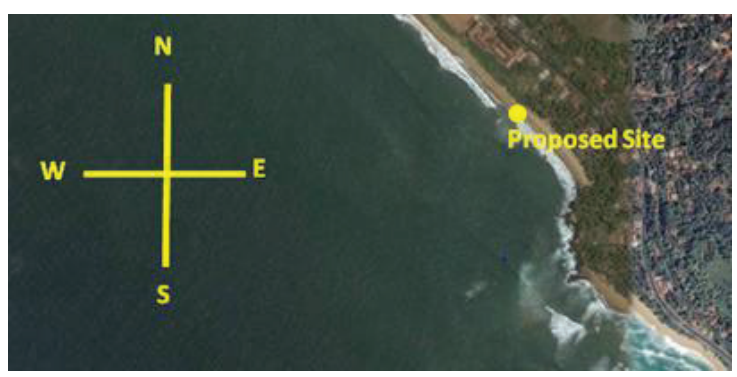

Figure 11 - Proposed Site in Galbokka (Source of Image: Google Earth Website)

The site is located in a wide sandy beach next to a rock outcrop as shown in Figure 11. From the rock outcrop, the beach extends uninterrupted for a few kilometres in the direction of Dodanduwa.

The investigation revealed a significant seasonal variation in the beach, in the order of up to $40 \mathrm{~m}$ in the vicinity of the project site, indicating high level of sediment activity. A beach profile with a steep gradient is formed at the site during the southwest monsoon, which, together with adverse wave conditions, makes it difficult for landing/mooring of fishing crafts. Due to the orientation of the beach at the site, as indicated in Figure 11, it is directly exposed to the south-west monsoonal waves and no sheltering effect is provided by the rock outcrop.

In view of the exposed nature of the site, it is evident that appropriate costal structures are required in any proposed development to provide a safe mooring and landing environment at the site. The layout of such structures will depend on local bathymetric and wave conditions but, based on the site conditions observed and considerations of exposure and protection requirements, a conceptual layout in the form of that shown in Figure 12 can be identified for further investigations. 
Fishery infrastructure facilities are usually developed in locations with a certain degree of natural protection and lower levels of sediment movement. The developments enhance the natural protection while causing minimum disturbances to sediment transport patterns to limit the adverse impacts in surrounding areas.

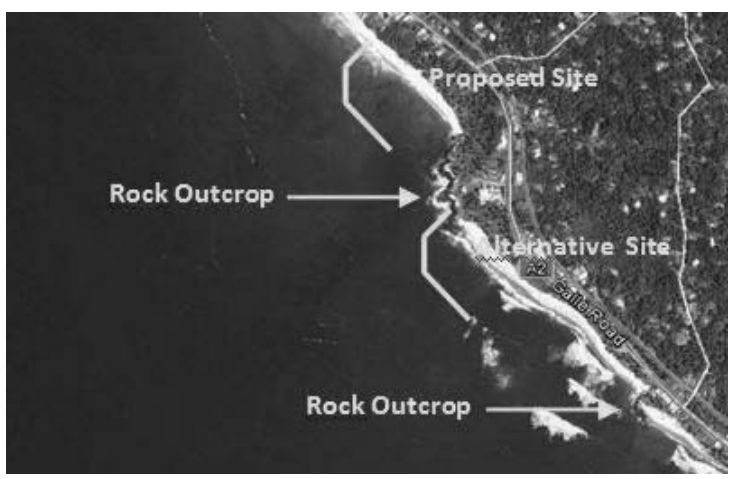

Figure 12 - Conceptual Layout(s) for Further Investigations

(Source of Image: Google Earth Website)

The costs associated with developing the facilities and providing impact mitigation measures can be kept relatively low by selecting appropriate locations for development.

However, no such natural protection exists at the site in Galbokka, located in a sandy beach with high levels of sediment movement. The protection for mooring and landing and loading/unloading operations needs to be provided entirely by coastal structures which could disturb the sediment transport patterns leading to potential coastline changes and erosion problems. In such a case, coast protection systems, usually in the form of groynes, may need to be included in the overall development plan. In view of these considerations, it is evident that the costs associated with any proposed development at the site proposed in Galbokka are likely to be significantly higher than the costs involved with a development of similar nature at a site with some form of natural protection.

\subsection{Investigations in the Alternative Site} In view of the potential adverse impacts associated with the developments at the proposed site, as an alternative, the technical feasibility of another site was investigated. It is located next to the proposed site on the opposite side of the rock outcrop, as shown in Figure 12.
The sandy beach at the site extending from the outcrop is interrupted by another smaller outcrop nearby (Figure 12) forming a smaller coastal cell in which relatively lesser extent of sediment movement is apparent. The larger outcrop provides partial protection from south-west monsoonal waves which can be enhanced by a coastal structure extending from the outcrop as shown in Figure 12.From a coastal engineering point of view, it is apparent that this site is more suited for development of fisheries infrastructure but, similar to the proposed site, detailed investigations are required to assess the development potential in detail.

\section{Investigations in Suduwella on the Southern Coast}

Suduwella in Kottegoda Bay was a Landing Site in the Matara District [1]. The expansion of fishing operations into deep sea with larger fishing crafts has led to the need to provide adequate infrastructure facilities for safe mooring and loading and unloading operations of such crafts operated in the area. The Kottegoda Bay (Figure 13) bounded by two headlands and facing southeasterly direction, had been identified as a suitable location for such a development. The southern part of the bay, Suduwella, (Figure 13) is relatively sheltered due to partial protection provided by the southern headland against south-west monsoonal waves. However, wave breaking and overtopping on a shallow steep faced reef, located closely and to the northeast of the southern headland, have resulted in an offshore directed current which has adversely affected the in and out navigation as well as mooring of larger fishing crafts within the area sheltered by the rocky outcrop. Due to shallow water depths, navigational difficulties and the absence of shore facilities, loading and unloading activities of larger fishing crafts were carried out away from the shore using smaller boats during the period of investigations in 2009.

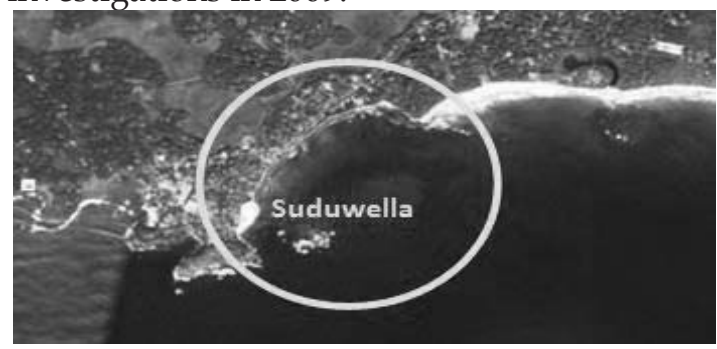

Figure 13 - Location of Suduwella in Kottegoda Bay

(Source of Image: Google Earth Website) 
The bay had been subjected to severe coastal erosion over the years which has necessitated the construction of a long revetment to protect the coastline. A fragile sandstone reef fronts the revetment, which is indicative of the severe loss of sand due to wave action. The only beach area within the bay exists at the southernmost corner in Suduwella, within the shelter of the southern headland.

Investigations were conducted to assess the feasibility of developing a Fishery Harbor of adequate capacity, which should provide safe navigational access and shelter throughout the year with minimal maintenance requirements and adverse environmental impacts.

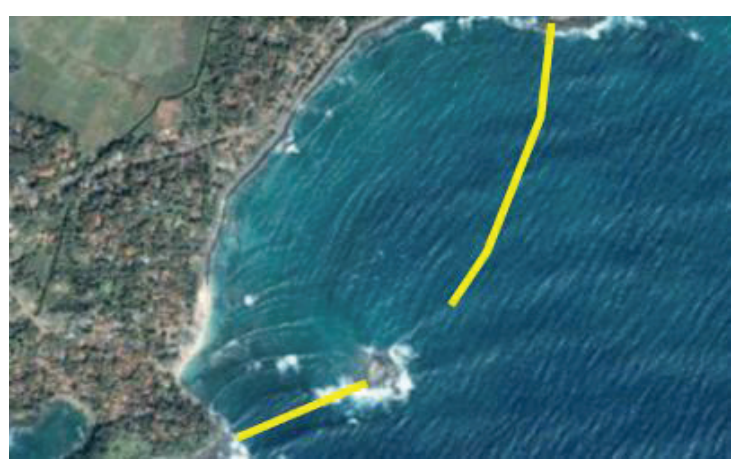

(a) Option 1

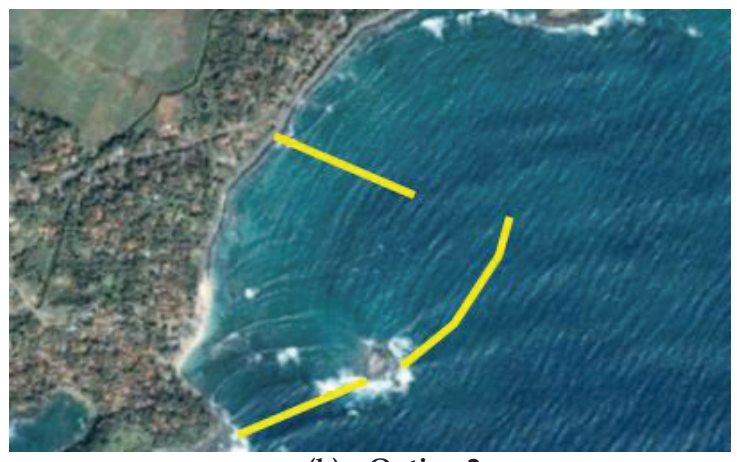

(b) Option 2

Figure 14 - Development Options for Suduwella

(Source of Images: Google Earth Website)

Studies had been carried out previously and two alterative layouts of development, one contained within the southern part of the bay and the other incorporating the entire bay, had been considered for further investigations.

In the layout of the Option 1 (Figure 14 (a)), the entire bay area was incorporated into a harbor protected by two breakwaters. The entrance was placed between the large rock outcrop towards the southern end of the bay and the head of the northern breakwater to facilitate the fishing crafts to use the path followed earlier by the fishermen. It was subsequently revised to provide safer access conditions by extending the southern breakwater beyond the rock outcrop.

In the layout of the Option 2 (Figure 14(b)), a harbor confined to the southern part of the bay, where fishery activities were concentrated, was conceptualized. The proposed harbor area is protected mainly by a southern breakwater which originates at the southern headland, connects with the rock outcrop and extends further in a northeasterly direction. The harbor entrance faces the northeasterly direction and is located in the gap between a secondary breakwater/groyne the main breakwater. Neither of these options had been implemented due various constraints associated with development. Investigations were thus conducted to identify a suitable development option within the constraints imposed to meet the stakeholder requirements. After extensive studies, in which attention was focused on coastal and harbor engineering, socio-economic and environmental issues, a conceptual layout, which is a modification of the Option 2 proposed earlier, was recommended for detailed design studies.It wasto be implemented in two stages, if necessary in view of any financial constraints. The designs were subsequently carried out and a Fishery Harbor facility was constructed (first stage) which is currently in operation (Figure 15).

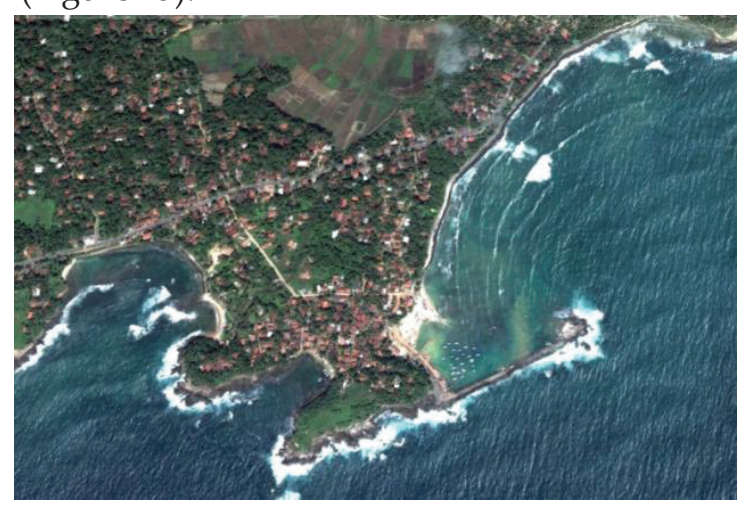

Figure 15 - Suduwella Fishery Harbor (Source of Images: Google Earth Website)

\section{Concluding Remarks}

The details of investigations conducted recently to assess the feasibility of developing sustainable fisheries infrastructure in various parts of the country are presented. These investigations were conducted in Vakari area on the eastern coast, Point Pedro area on the northern coast, Galbokka on the south-western coast and Suduwella on the southern coast. In the absence of recorded nearshore data at many of the locations considered, the 
investigations were mainly based on field studies, analysis of available secondary information and local knowledge gathered through community consultations. Although socio-economic aspects, availability of land for shore facilities and other related aspects were also considered in assessing the feasibility, attention was mainly focussed on related coastal engineering aspects to minimise the adverse impacts on the coastline in order to ensure the sustainability of the proposed development. As the investigations in Vakarai area revealed that the site identified initially is not favourable for development, based on further investigations, a location in Palachenai was identified as more suitable for further investigations for development. Investigations in Point Pedro area revealed that many of the existing Landing Sites can be developed further by enhancing the natural protection offered by the reef formation in the area. The need of a Fishery Harbor/Anchorage facility for the area was also became evident and the form of constructions required for such a facility was identified for further investigations. The investigations conducted in Galbokka revealed the potential for significant adverse impacts due to coastal constructions at the site initially identified for development, in view of which, an alternative site next to it was identified for further investigations for development. For the site in Suduwella, an initially proposed development option was modified to meet the stakeholder requirements within the constraints imposed and recommended for design studies. These were subsequently conducted and a Fishery Harbor facility was constructed which is currently in operation.

\section{Acknowledgement}

The authors wish to thank the officials in the Ceylon Fishery Harbor Corporation (CFHC), Department of Fisheries and Aquatic Resources(DFAR), United Nations Office for Project Services (UNPOS) in Sri Lanka and Japan International Cooperation Agency(JICA) for providing assistance to conduct the relevant investigations on fisheries infrastructure development.

\section{References}

1. Feasibility Study for the Development of Fishery Harbor/Anchorage at Suduwella, Kottegoda, Matara District, Interim Report submitted to United Nations Office for Project Services (UNPOS) in Sri
Lanka by Uni-Consultancy Services, University of Moratuwa, October 2009.

2. Feasibility Study for the Development of Fishery Harbor/Anchorage at Vakarai in Batticaloa District, Final Report submitted to United Nations Office for Project Services (UNPOS) in Sri Lanka by Uni-Consultancy Services, University of Moratuwa, January 2010.

3. Fisheries Infrastructure Development in Jaffna Peninsula, Final Report submitted to United Nations Office for Project Services (UNPOS) in Sri Lanka by Department of Civil Engineering, University of Moratuwa, September 2009.

4. Pre-Feasibility Study for Fishery Harbor Development in Point Pedro, Jaffna District, Final report submitted to Japan International Cooperation Agency (JICA) by Uni-Consultancy Services, University of Moratuwa, July 2011.

5. Samarawickrama, S. P., "Pre-Feasibility Study for Proposed Galbokka Landing site at Rathgama in Galle District for the use of Smaller Boats", Final Report submitted to Ceylon Fishery Harbor Corporation (CFHC), October 2010.

6. http://www.cfhc.lk, Visited 28 April 2014.

7. http://www.fisheries.gov.lk,Visited 28 April 2014. 